\title{
Selected Issues Illustrating Duality in Relation to Lakota Identity
}

\section{KLÁRA PERLÍKOVÁ}

Institute of Ethnology

Charles University, Prague, Czech Republic

klara.perlikova@gmail.com

\begin{abstract}
The article deals with selected issues which - as we perceive it - can provide an insight into what the Lakota consider essential and generic for their self-identification with their culture (What does it mean to be Lakota?). The study is based on observations gained during fieldwork research, and issues in the text reflect data collected within this period. As a result, we examine the following issues: tribal museums in Lakota reservations, Native perception of time, selected issues of Lakota religion, and Lakota relation to the land and environment they live in and to the world on a global scale. We believe that in all these issues we can also recognize an underlying dual structure which - in its most general meaning - could be understood as a dichotomy of Native and Western/Euro-American worldview and mind-set. The question was how non-Native elements distort or affect the system of Lakota culture. In the section on tribal museums and perception of time we have shown that circular way of thinking about the course of the world which is, according to Donald Fixico (FIXICO 2009), characteristic of all Native cultures affects the way tribal museums organize and present their exhibitions. In this case, the influence of the Native/Euro-American dualism does not have to be necessarily negative. The same can be said about another example where the dichotomy projects itself - in the issue of Lakota relation to the land or Unci Maka (Grandmother Earth): Though Lakota religion and identity is regionally bound (BUCKO 2008), their concern for this integral part of their Native-self
\end{abstract}


can surprisingly well fit into the global issue of protection of environment. On the case of Lakota struggle to stop construction of a KXL pipeline ${ }^{1}$ we demonstrate how the same (Native/Euro-American) duality interacts and through which the Lakota (Native, regionallybound) voice is strengthened by its non-Native counterpart and vice versa.

KEY WORDS: Native American, Lakota, identity, tribal museums, linear and circular time

\section{Introduction}

"For the majority of some million and a half variously defined Indians in America, being Indian involves not just the traditions or catastrophes served on a buffalo chip of history, but a conscious set of choices. The central issue is what to fuse of the new and the old, improvisations and continuations from the past." (LINCOLN - SLAGE 1997).

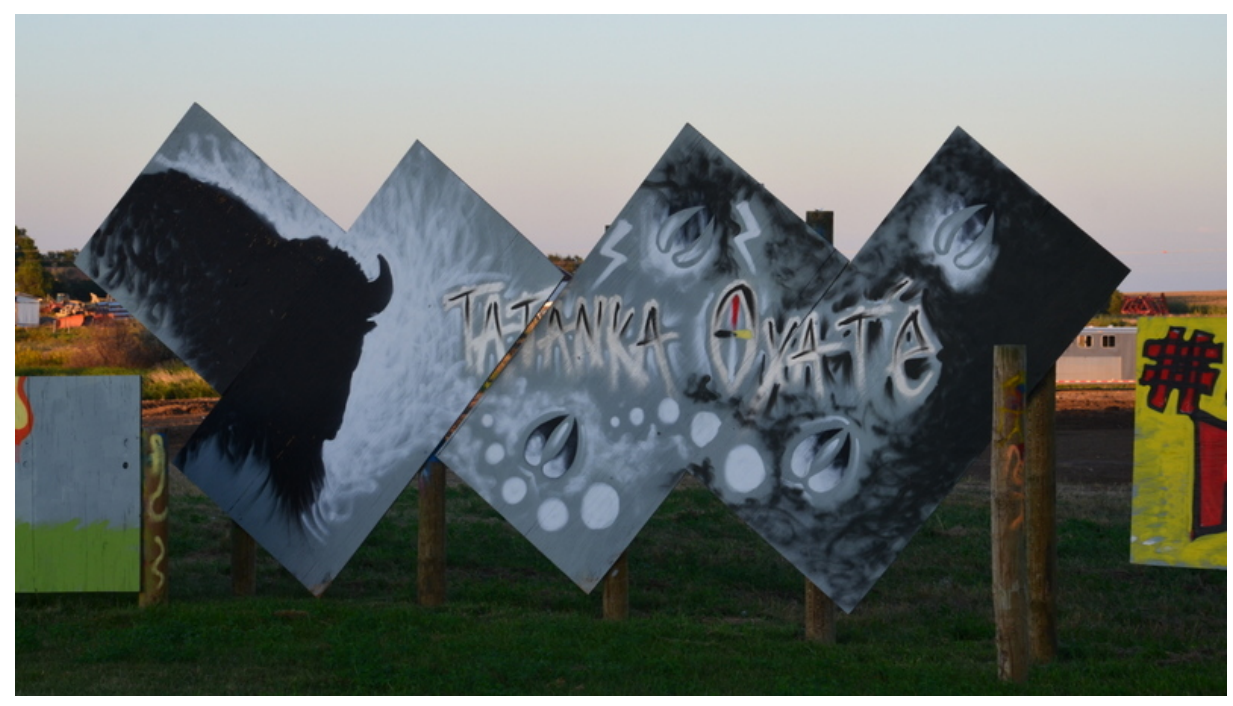

Figure 1: Grafitti in Eagle Butte, South Dakota. Photo: K. Perlíková 2015.

The project of $\mathrm{KXL}$ pipeline is explained in more detail further in the text in a section with the same name.

DOI: 10.1515/eas-2017-0011 C University of SS. Cyril and Methodius in Trnava. All rights reserved. 
The issue of Lakota identity is from a large part similar to a broader topic of Native identity of other tribes of North America, or "being Indian" as the term has become known ${ }^{2}$. As Cash and Hoover write, "Indians have also been the subject of more than thirty thousand books, but very few address what is it like to be Indian" (CASH - HOOVER 1995:x). In this paper, we do not intend to provide an ultimate and unambiguous answer to this question, but it is important to realize that until recently this topic has been not been written about frequently, since works on Native American history, ethnography of narratives have prevailed.

This article is a part of the author's dissertation thesis which focused on the culture of the Lakota in a more general sense. The issue of Lakota identity is discussed in the dissertation as one of its chapters. It is based on the data collected in two month-long fieldwork researches in Rosebud, Pine Ridge and Standing Rock Indian Reservations. We have visited these places in summer and focused our attention on powwows which take place frequently in this season. At these gatherings we were collecting the data on the contemporary form of Lakota culture through observation and also through unstructured and semi-structured interviews with the Lakota who gave us their permission. Some interview partners preferred the form of a narrative interview.

We are aware of the fact that a Lakota powwow represents only one (though very important) aspect of the way the Lakota reflect on and represent their own culture, and that elements of culture stressed at these events can less pronounced in everyday life of the Lakota. In terms of bibliography our research on Lakota identity relied on works of several Native scholars who write about the subject. However, it is also important to realize that in their books they stress some elements of their culture, and that Lakota families who find themselves in the marginalized position in relation to mainstream American society would consider such imagery idealised or not corresponding to reality. For this reason, it is definitely not possible to generalize the statements and interview partners' feelings and views of Lakota identity (or identities): The arguments presented below are always based either on an individual's experience or observation or on scholarly interpretations of the identity issue. However, we could always find Lakota people whose point of view would differ from the one presented in the text. Having in mind all these relativizations, we can

2 The term „being Indian“ is used by many scholars who have contributed to the issue of Native American history, culture, narratives and other areas. For example Joseph $\mathrm{H}$. Cash and Herbert T. Hoover (CASH - HOOVER 1995), Robert R. Berkhofer (BERKHOFER 1978), Donald Fixico (FIXICO 2009) or McNickle (McNICKLE 1993).

DOI: 10.1515/eas-2017-0011 C University of SS. Cyril and Methodius in Trnava. All rights reserved. 
proceed to the issue of Lakota identity itself. How is perceived and presented by the contemporary Lakota, and how does it transform in the modern world? What do the Lakota consider generic for the self-identification with their culture (What does it mean to be Lakota)? These are the basic questions discussed in the article.

To be Indian (and therefore to be Lakota) can be characterized in many ways and many words. Fixico wrote that "to be an Indian meant being alone in dominant society and its culture." Further, he explains that term

“(...) is a statement full of political meanings and cultural complexity. An Indian person is subjected to many political definitions at various levels of tribal politics and by state and federal bureaucracies. The conflicting formulas of official tribal acknowledgement, federal blood quantum, and self-identification contribute to a sense of ambivalence. This experience is complicated even more by social and cultural identifications. To be Indian involves a spectrum of identities raging from a generic Indianness to tribal culture, social need, societal judgement, and psychological self-examination.” (FIXICO 2009:ix).

In the following paragraphs we are going to deal with Lakota identity, which can be - in our point of view - perceived as a dual one, mainly because of the existence two cultural norms - Western ${ }^{3}$ and Native - which are often hardly compatible with each other. Using Fixico's words, we can perceive them as "conflicting formulas." This conflict is more or less obvious in many aspects of life and culture of the Lakota, beginning with their history and how the cultural heritage has been dealt with.

\section{Tribal Museums and Identity}

Let us start with museums of Lakota cultural heritage, history and arts. In the area of Rosebud and Pine Ridge reservations, there are at least four official institutions which serve as tribal museums. The phrase at least is used on purpose. Apart from buildings fulfilling the concept of museum as a public place of meeting and a depository for collecting, preserving and sharing knowledge about objects having historical or artistic value there are many unofficial improvised "museums:" Native artists display their works directly at their homes. They are not professional craftsmen, and they do not make a living from their

3 By the term Western we mean Euro-European, non-Native.

DOI: 10.1515/eas-2017-0011 C University of SS. Cyril and Methodius in Trnava. All rights reserved. 
artistic works, since visitors (and tourists) are rare in the area. The concept of museum is in these cases re-defined: it was not established as a place of displaying a large number of artistically valuable objects; what is of primary concern here is the need to share with anyone interested in anything about the artist's culture. We can probably perceive it as another form of the need of sharing traditional knowledge which is described in Albert White Hat Sr.'s book Zuya (WHITE HAT 2012). In it he described the purpose of his project in which Lakota medicine men gave series of lectures on traditional Lakota culture for students of various programmes at Sinte Gleska University in Rosebud: "We saw a need for our students to know something about our culture in order to connect with people who held those beliefs." (WHITE HAT 2012:xvii). As A. White Hat Sr. pointed out, the medicine men, contrary to general expectation of his University colleagues, agreed to teach the courses, because they perceived it as an opportunity to overcome the image of traditional Lakota culture and spirituality as illegal and undesired, which had been an official rhetoric imposed by federal government in reservations for a long period of time:

"For nearly one hundred years we had been taught to believe our traditional ways were evil, that we worshipped the devil, and were pagans. This was the message we received in our education, and it became the predominant feeling among our people. It was also the reason why the medicine men agreed to teach" (WHITE HAT 2012:xix).

These improvised museums can be perceived as a similar expression of the need to eradicate the remains of the colonial past. Native artists set up their exhibitions in order to "connect" and "share"," rather than exhibit or sell their works. They can be found in private homes, far from main highway going through reservation, and are indicated only by hardly visible hand-painted notices.

Besides, there are of course official and larger museums of Lakota history, art and culture. In the area of Rosebud Indian Reservation there are two such museums ${ }^{5}$ : Lakota Museum at

$4 \quad$ David Long Soldier. Interview, September 2015.

5 Of course we can find much more museums of Lakota culture that are situated in four Lakota reservations in North and South Dakota: Pine Ridge Indian Reservation, Rosebud Indian Reservation, Standing Rock Reservation and Cheyenne Sioux Reservation. The two museums in Rosebud reservations are used as examples of how Native Americans' (Lakota) approach to this institution varies from the Western concept of a museum, and they certainly do not capture the situation of all the Lakota tribal museums. We are aware of this fact and perceive these two as illustrations of our observations. However, as Z. Buchowska showed in her presentation on tribal museums, many of there aspects are universal and true for tribal museums all over the United States (presentation at American Indian Workshop 2015 in Frankfurt). 
Buechel Memorial in St. Francis, and Lakota Heritage Center at Sinte Gleska University campus near Mission. When a visitor enters these two museums, at first glance he or she will be probably surprised by the beauty and aesthetic impressiveness of objects displayed there. One can see radiant star quilts and a large number of various richly-beaded objects: pow-wow regalia, ordinary caps decorated with beadwork, belts or even fully beaded Converse trainers. All of the exhibits do not seem to be chosen for the reason that they are old, and therefore, from the Western perspective, valuable, ${ }^{6}$ because many of them were made relatively recently, not more than 30 years ago. It is evident that the objects displayed there were chosen for exhibition primarily for their outstanding aesthetic value. While Western museums of Native American cultures prefer to display pieces which fulfil the idea of an ancient/traditional (historical, old, made of leather or buckskin) Native American object, Lakota museums in Rosebud prefer to show their visitors the finest pieces of Lakota art, and the decisive factor is not the old age of the given object or the material it is made from, but its aesthetic superiority. This difference in attitudes to what is worth displaying might explain why we never come across Native American star quilts in European museum: they are probably not considered traditional or genuine Native American craft, since Lakota women started to make them relatively recently, ${ }^{7}$ and the material they are made from is usually fabric.

The difference in the character of Lakota and European museums, illustrated by the example above, should be reflected from a more general perspective: Many scholars who come from Native communities all across the world perceive museum as an institution of European imperialism and colonialism, ${ }^{8}$ which is still a strong agent in creating a (false) image of contemporary indigenous communities not only of North America, but also of other parts of the world. L. T. Smith, a Maori scholar, criticises European anthropologists

$6 \quad$ In case of Western museums we can observe a rough correlation between the age and value of the exhibit. During my visits at ethnographical museums in Prague, Berlin and Vienna we could hear the phrase "this is valuable, because it is very old" many times.

7 Ollie Napesni, a „Lakota living trasure,“ a story teller, „carrier of culture,“ a Lakota language teacher, and star quilt maker and a lifelong resident of the area of Rosebud Reservation in South Dakota has shared her memories and her life story in a book Salt Camp. In it she writes about the origins of star quilt making among the Lakota from the area of Rosebud. Ollie Napesni remembers that she saw and then made her first star quilt in 1959, and the art of star quilt making, which originates from the Amish, has spread among Lakota women relatively recently: "You know, it's just recently that they really started to make them here because when I came back I never did see quilts and if there was anybody that had quilts they were like blocks or triangle shapes" (NAPESNI 2003:214-219).

8 See for example Linda Tuhiwai Smith's book Decolonizing Methodologies (SMITH 1999).

DOI: 10.1515/eas-2017-0011 C University of SS. Cyril and Methodius in Trnava. All rights reserved. 
and ethnologists for misusing their power of an educated authority in the society to create an unrealistic image of her community by selecting informants who fit into their idea of a Maori: "They had a deep sympathy towards Maori people as an ideal while being hostile towards those Maori who fell short of this construct" (SMITH 1999:86). Similarly, the Lakota refuse the false image of their culture created by museum institutions, anthropologists and also by various hobbyist" groups, which is the image of the "Grateful Dead Indian" (DELORIA 1999:182). Although the Lakota have been continually transforming their style of living to fit the $21^{\text {st }}$ century America, until nowadays they are too often conceptualized as people of the nineteenth century. White Hat Sr. has expressed his disappointment at this prevailing image of the Lakota like this: "Our rituals have been dramatized and colored with a mysticism and mystery that are simply false. Our lifestyle has been romanticized, and in many cases we're presented as history. Our cultures are history, and we no longer exist" (WHITE HAT 2012:27). When we read White Hat's comment, which speaks for many Lakota and other Native American people, it becomes evident that Buechel Museum in Rosebud and other tribal museums are trying to fight against this stereotype of Lakota people as a nation of the past also by the selection of objects exhibited; they show contemporary objects and pieces handcraft (e.g. modern powwow regalia or star quilts). In fact, their message is supposed to be the opposite: Lakota tribal museums attempt to show that Lakota culture is a part of the present rather than of the past. As was stated by representatives from a variety of indigenous cultures who were asked by National Museum of the American Indian to reflect on their heritage in the museum's collections:

"In the future we don't want to end up engraved in a museum's exhibit. We want our music and dance, our songs to our nature, to our homes, and to our motherland performed by our people themselves while they are alive. We don't want to be thought of as dead people to be exhibited in a museum" (National Museum of the American Indian 1994:184).

On the other hand, tribal museums exhibit a large number of objects that are, from the Western perspective, historical artefacts: objects of daily use such as horn spoons, moccasins, baby cradles, arrow heads or bone combs from the pre-reservation era. We can

$9 \quad$ Hobbyism is a very wide term. It is used to label an unofficial movement of people both from Europe and United States who are interested primarily in reenactment of what they believe are Native American cultures, usually in the form of the pre-reservation era. Though the large number of hobbyists is also concerned to be in touch with the contemporary form of Native American cultures, hobbyism is often associated with romantic stereotypes about Native Americans in their pan-indian form.

DOI: 10.1515/eas-2017-0011 
see a collection of ledger art drawings which is almost 100 years old, and Buechel Museum boasts a unique collection of winter counts - the oldest of them dating back to 1800 's $\mathrm{s}^{10}$. How do these exhibits fit into the concept of a Lakota tribal museum which we claim to be different from the Western museums concerned with Native American (or Plains) cultures? And how do they support the image of the Lakota as not being a part of "history"? Answers to these questions are based on the difference between the perception of time by Native and Western people. Euro-American way of understanding time is characterized by its linear course from the past (or history) through the present towards the future. The Lakota (and Native Americans in general) perceive the world through different lens. Donald Fixico, a Native American (Shawnee, Sac and Fox, Muscogee Creek, Seminole ${ }^{11}$ ) scholar deals with the distinction between Western and Native worldview in a book The American Indian Mind in a Linear World (FIXICO 2009). He characterizes the Native American philosophy as a "circular" one, because it is based on perceiving the world and its order through constantly alternating stages of cycles, both on the individual and the most universal level: the migration patterns of animals, cycles of seasons, and what he calls "Natural Order of Life" (FIXICO 2009:42). For Fixico, the circular way of perceiving the world is universal for all Native Americans and forms the basis of differences between Native and White Americans. He explains the concept of circular philosophy in the following words:

"Like the season changing in cycles every year and like the day and night in a circular change, the circle of life includes all things, according to Indian belief. The past is a part of the present such that history is a continuum without a beginning or an end in the Indian mind" (FIXICO 2009:45).

Though Fixico is not a Lakota, we can see that the "circular" Native logic can be thought of as universal indeed, because in Buechel and Sinte Gleska museums history is approached precisely from this perspective - as a part of the present. For example, many exhibits which illustrate the life on the plains in past times, such as bone instruments and pieces of garment are displayed with a label saying who was the original owner, and eventually which family he or she was a member of. Since membership in a family or tiospaye, ${ }^{12}$ and the contact

10 The so called winter counts are displayed in a separate room, and it is strictly prohibited to take photographs or videos of these exhibits.

11 Though we further write that Donald Fixico was raised Seminole and Muscogee Creek, Fixico's origin is - in terms of biological ancestors - more complicated.

12 The explanation of this term, which can be crudely translated as "family" or "family clan" can be found for example in a book a book Zuya by White Hat Sr. (WHITE HAT 2012).

DOI: 10.1515/eas-2017-0011 C University of SS. Cyril and Methodius in Trnava. All rights reserved. 
with relatives and knowledge of one's ancestors and their life stories is very important for the Lakota, we can understand the non-anonymous character of the exhibits as an active link between living members of a tiospaye and their deceased relatives, who - through their names in the museum - share their wisdom with future generations, or, as the quote above says, "they are a part of the present". Furthermore, names under museum exhibits are not the only symbol of fulfilling the idea of Lakota circular Natural Order of Life. Tribal museums intentionally represent the crafts mastered by and the knowledge of previous generations as a fundamental part of education of present-day children, because various pre-school or elementary school classes are frequent visitors here ${ }^{13}$. For example, in a section dealing with the importance of buffalo for the Lakota, there is an interactive exposition titled "Can you guess what kind of useful items can be made of buffalo hides and hair?" It explains how various parts of the animal can be used for making clothes, instruments, food or dishes. What is important, the labels are always in present tense, and also the photographs and illustrations are intentionally related to the present-day use.

The general knowledge and certain skill in crafts of the pre-reservation era among modern Lakota is not maintained only by tribal museums. Until nowadays, it is required in various situations and stages of life of a person, as two quotes bellow illustrate:

"On the occasion of her coming of age ceremony ${ }^{14}$ a girl must be able to pick up a tip̄i on her own to show she can take care of her future family"15.

One can hardly see a tipi $i$ as a normal dwelling. On the other hand, it is a necessity on various special occasions and ceremonies.

"Every summer we would go camping in Ghost Hawk with children. We would live in tipis, prepare food in a traditional way, ${ }^{16}$ speak Lakota, tan hides and many more things. We have wonderful times every year. "17

13 Though we have visited the museums during summer holidays, every time we were there, we met a pre-school/elementary class of Lakota language and culture studying and talking about the exhibits. As the teachers explained, they consider visiting the museum crucial for the children's understanding what it means to be a Lakota. A teacher of Lakota Language Summer Elementary School. Interview, July 2014.

14 White Hat Sr. writes about this ceremony and explains that the Iśnati ("Living alone") ceremony is done for the first few months after a young girl experiences her first monthly period. For the description of the ceremony see (WHITE HAT 2012:51-52).

15 A Lakota woman in her fifties, she has four daughters and seven granddaughters. Interview, September 2015.

DOI: 10.1515/eas-2017-0011 C University of SS. Cyril and Methodius in Trnava. All rights reserved. 
In school curriculum of every stage we can find courses in Lakota language and culture, and there are many activities among the oldest generation to promote their knowledge, and make their language and culture literally a living part of the lives of their children and grandchildren.

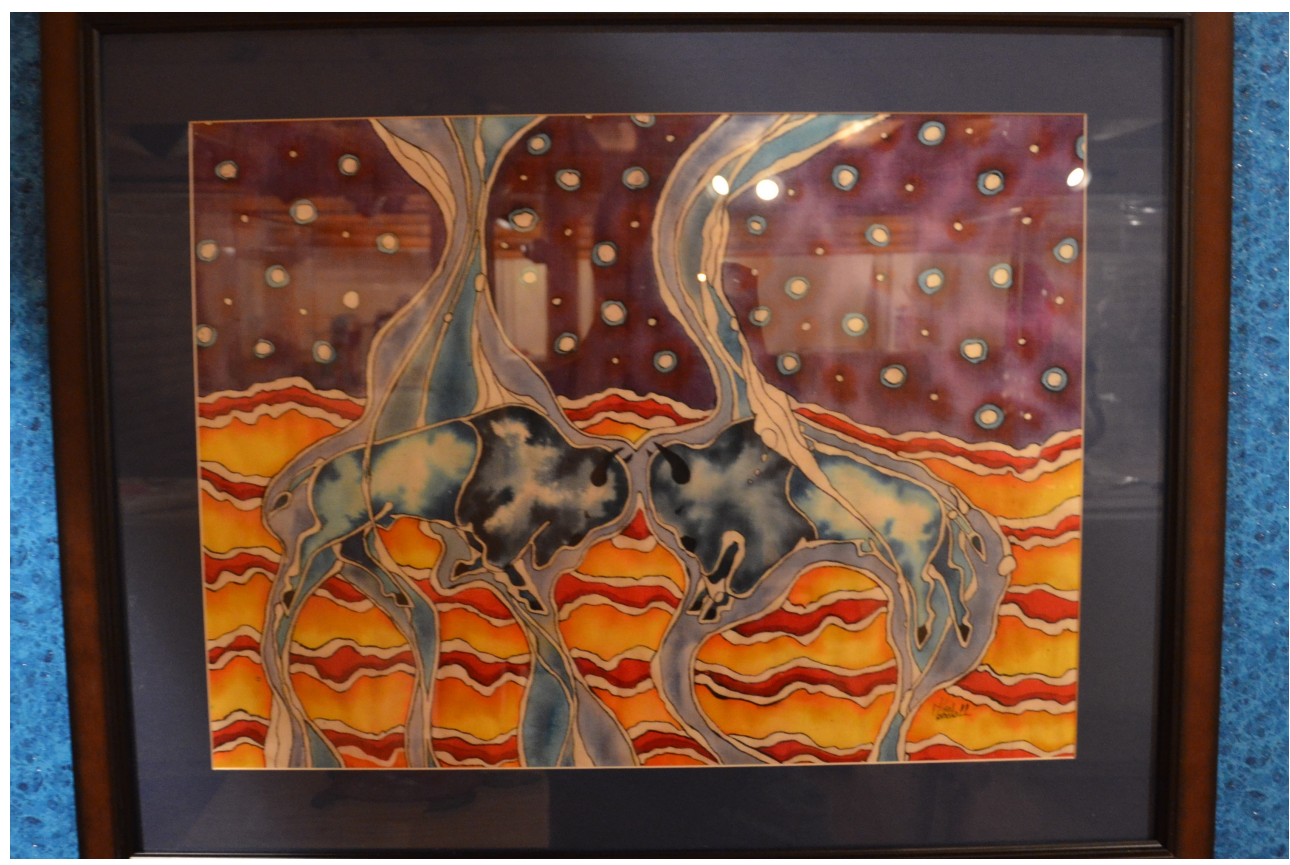

Figure 2: Contemporary art exhibited in Lakota museum at Sinte Gleska University. Photo: K. Perlíková 2015.

\section{Linear and Circular World}

In the previous section Fixico's reflections on the difference between circular - Native and linear - Western perception of time were mentioned. When we think deeper about what Fixico wrote about the difference between Western and Native concepts of history and course of time, we realize that the disparity between these two must be perceived as a

16 She explained that means to put pieces of meat, herbs, vegetables and water into the raw buffalo stomach, then throw in fire-heated stones, and let everything until cooked.

17 A Lakota language teacher in her sixties. Interview, September 2015.

DOI: 10.1515/eas-2017-0011 C University of SS. Cyril and Methodius in Trnava. All rights reserved. 
structural one in the sense that it affects the most general elements of culture. One of the most important of these elements is the Lakota perception of natural environment, which influences many issues the contemporary Lakota have to deal with. For this reason, we will proceed with the issue of linearity and circularity a little bit further.

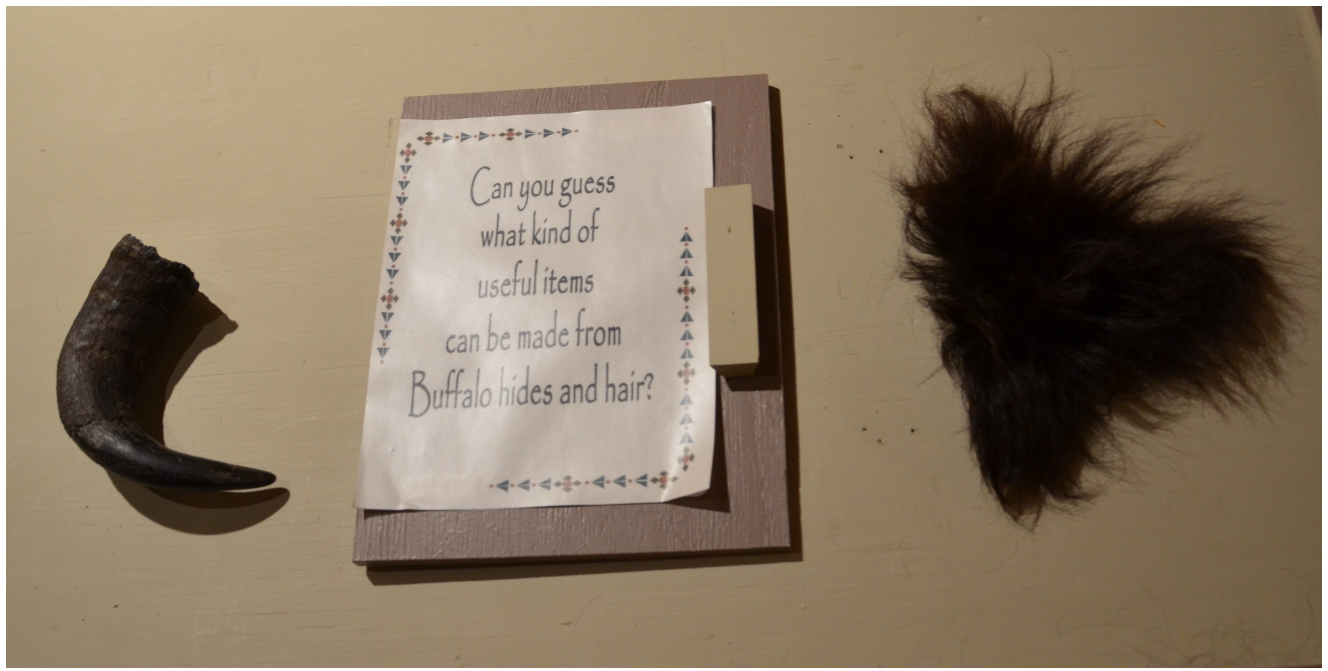

Figure 3: From an exhibition in Lakota museum at Sinte Gleska University. Photo: K. Perlíková 2015

As it was mentioned, Native Americans' basic concepts of perceiving and understanding the world we live in radically differ from the worldview shared among Euro-American society, although there are of course many sub-cultures who fit more in the "Native" system of values. How a person understands the idea of time is one among the basic radically different concepts, as the Native quote below puts it:

"(...) the concept of time for Indian people has been such a continuum that time becomes less relevant and the rotation of life or seasons of the year are stressed as important for understanding life. This is inherent to understanding life for American Indians. It is also inherent to mainstream Americans and the rest of the world, although time is less of a factor for comprehending the changes or phases of life from birth to childhood, to adulthood to old age, and to death" (FIXICO 2009:72). 


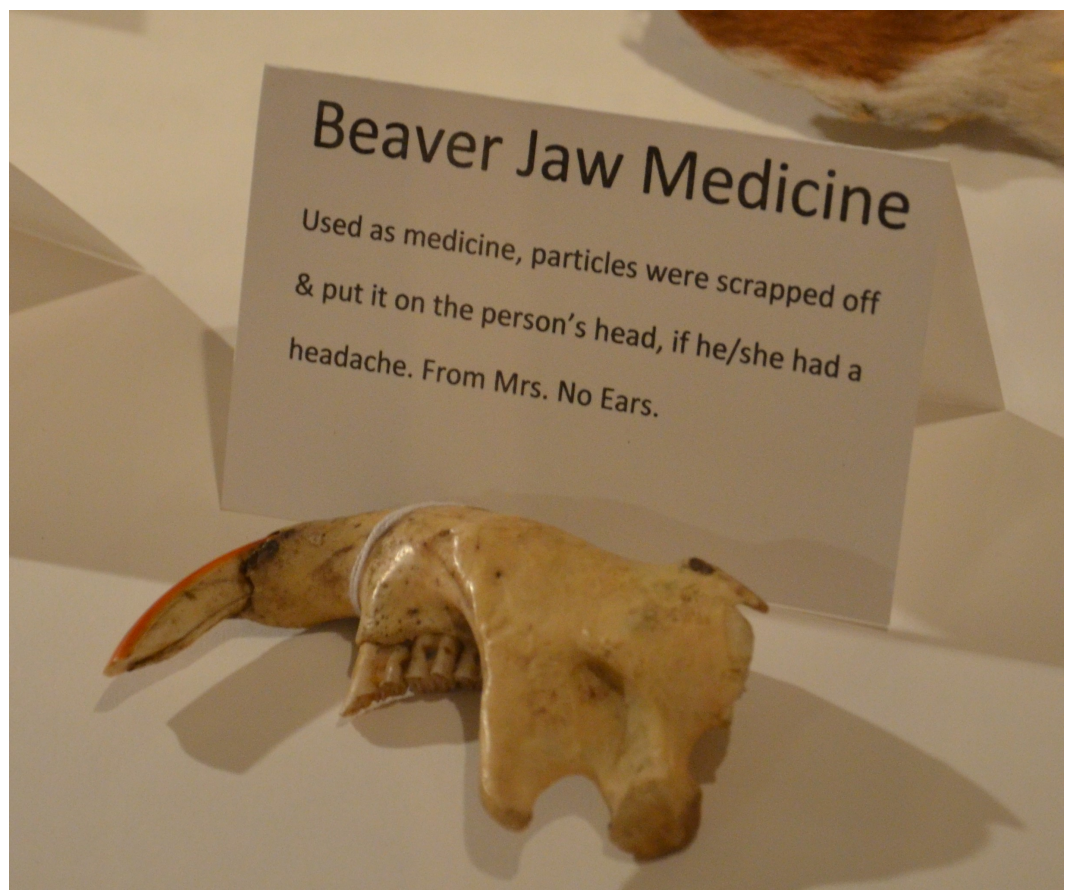

Figure 4: From an exhibition in Lakota museum at Sinte Gleska University. Photo: K. Perlíková 2015.

Fixico was raised as a Seminole and Muscogee Creek, but when he writes about Native Americans and their "non-American" values, he makes no tribal distinction, and stresses repeatedly that all indigenous people of North America share a similar philosophical heritage, and that they have in common their dissimilarity with the non-Native American majority. In the quote above, Fixico states that people both in Native (Indian) and Western worlds have always been aware of two types of time - linear and circular one - being in conflict in a mind of any living person. For people living in Euro-American society the linearity of time and the flow and progress of an individual's life from birth to death, from the unreturnable past to uncertain future, or from cause to effect has become the primary way of perceiving the world, and although Euro-Americans are aware of the repeating pattern of changing seasons of the year, they do not consider its circular character important or relevant enough to their lives: every beginning of a new year or every new-born baby is perceived as unique and new. In other words, the Western civilization gradually ceased to 
perceive the world through the circular pattern which Fixico considers the primordial one, whereas Anglo-American people have become a linear society through their obsession of measuring time.

For Native Americans, on the other hand, the perception of time is based on the repeating cycles of natural creation, death and re-creation. Life emerges in spring, grows and ripens during summer and autumn, then everything ceases to live in winter only to emerge again in spring with new energy to repeat the cycle of the year once more. From the Native perspective the life of an individual, perceived by Western philosophy as linear, makes sense only within the context of the circular life of nature and everything living in it. Human life is understood as a sequence of events or stages which have a form of a circle from life to death, and this cycle repeats itself from generation to generation ${ }^{18}$. The uniqueness of an individual and his or her short life is regarded as unimportant in view of the course of natural processes: what is central is the regularity and stability of cycles.

It is evident that the difference between the concepts of time in Native and Euro-American cultures determines other basic notions of the given culture. If Native Americans consider the circular concept of time primary and natural, their idea of a meaningfully lived life has to differ from the Euro-American notion. Fixico considers order and relationship the most important concepts of Indian culture which represent both the way how to reflect the world and the key to live a meaningful life for an American Indian:

"How atoms, objects, humans, or entities in general are related or associated with each other is imperative to an individual's understanding and comprehension of the world and the universe. According to the Creator, all things are in a sequential order called the Circle of Life. Relationship and order are essential concepts that help to understand the native ethos of Indian people" (FIXICO 2009:73).

Let us first take the term "relationship," and reflect on what meanings it gains in the context of Lakota culture. First, there are of course family relationship - the concept of tiospaye we have dealt with above. It is not only a Lakota name for a formal concept. The term

18 A Lakota woman, the wife of the former president of Rosebud Sioux Tribe explains the Lakota idea of the Circle of Life and its seven stages and rites connected with them through the following diagram: The circle begins with Birth followed by the Wiping of The Mouth ceremony. The third stage of one's life is marked by the Making Relatives rite. Later, there is the fourth ceremony, Coming of Age. In another stage of one's life, there are other two ceremonies, Keeping of the Soul, and Wiping of Tears. The seventh stage of life is Death, which is perceived as the return to Birth, and the circle is complete. Interview, July 2014.

DOI: 10.1515/eas-2017-0011 @ University of SS. Cyril and Methodius in Trnava. All rights reserved. 
describes a family system in a sense much more complex than the Euro-American idea of each individual's family. Additionally, the membership in a tiospaye is defined not only through biological kinship, but also through marriage or adoption. However, what is always crucial is the way members of a tiospaye express their feelings towards their relatives: relationship is expressed through showing love and affection to family members, especially to children. In the following quote, Mildred Stinson, an Oglala Sioux remembers her childhood during 1920's and describes how grandparents and other relatives always dealt attentively and lovingly with children:

"There was always much affection; they put their arms around us and sitting close to them, be sitting around, aunts would reach over and get us and set us on their laps. And things like that. There was always love" (CASH - HOOVER 1995:94).

Despite the fact that Mrs. Stinson's memory comes from a several decades' time ago, we have observed many times that among contemporary Lakota children are treated with a similar love and affection ${ }^{19}$, especially by the oldest generation. What in Euro-American point of view would have been labelled spoiling a child, is a part of expressing love and respect among members of Lakota tiospaye. Similarly, the same affection which is often showed towards the youngest members is reserved to the elders of a family, since grandparents are respected for what they can teach their grandchildren ${ }^{20}$ and because "grandchildren is their [grandparents'] happy preoccupation" (DELORIA 2007:23).

When reflecting on the term "relationship" in the context of Lakota culture, we have to

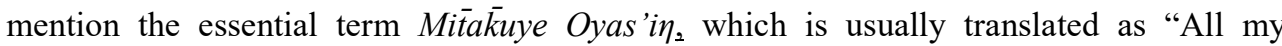
relatives" or "We are all related." It is understood as a concept, and White Hat Sr. explains it in this way:

"This is the most fundamental belief in our Lakota philosophy, that we are related to everything on earth and in the universe. We were all formed from the blood of Inya ${ }^{21}$ :

19 Of course, this tradition is not a cultural imperative strong enough to prevent some Lakota parents from mistreating their children. The problem of child abuse is not unknown among Lakota, as shows a video-spot by a Native sketch comedy group „1491s“ which intends to support a campaign for positive parenting approach in Lakota families. The video is available on https://www.youtube.com/watch?v=TJHQutcSFQU.

20 When we attended a powwow which happened to take place on the Grandparent's Day, there were numerous honour songs to honour grandparents, and grandchildren were asked to thank and express affection to all grandparents.

21 The Lakota word for stone. According to Lakota mythology, Inyan was the first being in the world and from it everything else came to be.

DOI: 10.1515/eas-2017-0011 C University of SS. Cyril and Methodius in Trnava. All rights reserved. 
humans, animals, trees, water, air, stones. Everything in the universe, we are all related" (WHITE HAT 2012:33).

The concept is referring directly to the Lakota creation myth, and for those who adopt the philosophy and live it every day, ${ }^{22}$ Mitakuye Oyas 'in represents a way how the environment they live in becomes an integral part of their Lakota identity. This deep interconnection is not only symbolical. We can truly perceive landscape of the Great Plains region as a physical representation of Lakota concern for the environment they live in. As Kenneth M. Ames stressed, the landscape is inseparable from Native culture:

"Better to speak about landscape in connection with Native Americans and reservations: Landscape defined as the "material manifestation of the relationship between humans and the environment" (AMES 2008:8).

The Mitakuye Oyas'in concept teaches the Lakota to respect and use wisely everything that lives, grows and stands around them as their relatives - an approach completely different from the Euro-American view of nature and the resources it provides. ${ }^{23}$ Quite recently, the Mitakuye Oyas'in philosophy has gained a very contemporary dimension, when a mining company TransCanada started a project that proposed building tar sands pipeline from oil sands in Canada to refineries in Texas. One of its segments, known as Keystone XL (or KXL) was planned to run also through the Great Sioux Nation treaty lands as defined by the 1851 and $1868 \mathrm{Ft}$. Laramie Treaties. This project has been practically halted both by the presidential veto in November 2015 (LABOTT 2015) and by significant fall in oil prices that made the project unprofitable. However, the protests against construction of the northern segment of KXL running through South Dakota reveal how Lakota culture, identity and especially their relation to natural environment are a part of contemporary cultural awareness of the Lakota. What is more, the arguments against the KXL pipeline derived from the concept Mitakuye Oyas 'i $\eta$ have formed protests going beyond borders of reservations and became a basis of a unique alliance between Native and non-Native residents of the affected area. For this reason, we will use the case of Keystone pipeline to

22 As with other aspects of Lakota culture, also the concept of Mitakkuye Oyas'in is now taught to Lakota children both in pre-school and in higher classes, in order to support the revitalisation initiatives of Lakota culture and traditions.

23 There have been many books and works dealing with the history of clashes, disputes, disagreements and armed conflicts between the Lakota and Euro-Americans colonizing their territory. One of the books that describe more recent history of Lakota resistance to federal government's policy towards Native Americans is E. C. Valandra's Not Without Our Consent (VALANDRA 2006).

DOI: 10.1515/eas-2017-0011 C University of SS. Cyril and Methodius in Trnava. All rights reserved. 
show how the Lakota understand and apply the philosophy of Mitak $\bar{k}$ uye Oyas'i modern world, and what forms it can take.

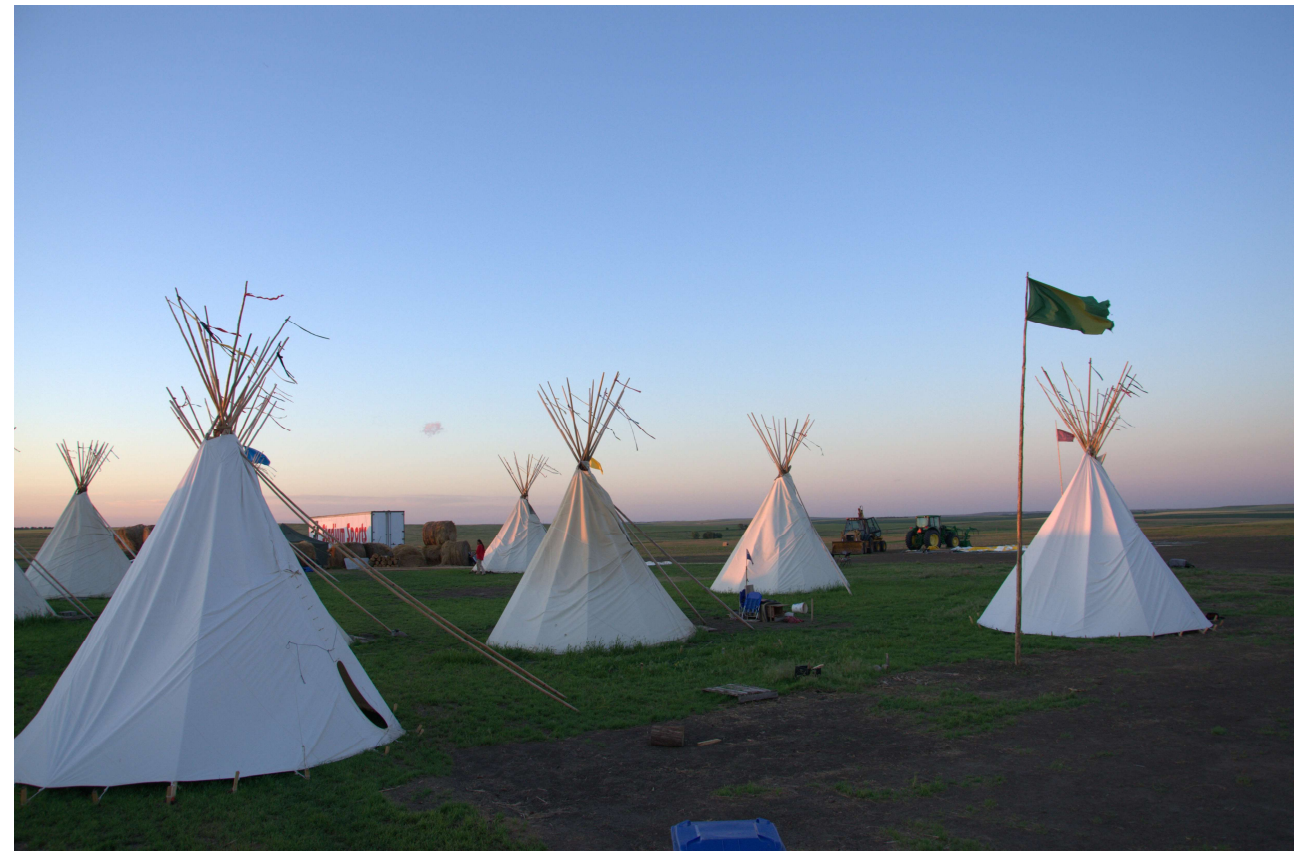

Figure 5: Spiritual Camp in the trail of the proposed KXL Pipeline near Winner, South Dakota. Photo: K. Perlíková 2014.

\section{KXL Pipeline ${ }^{24}$}

The Lakota opposed the construction of the Keystone pipeline from the moment the project had been announced. Their protests were organized mainly by the actions of Rosebud Sioux Tribe and their initiative "Shield the People" (Oyate Wahacanka Woecun). In March 2014

At the present time (2017), a similar project with similar reasons for protesting against it - Dakota Access Pipeline (DAPL) - is being built in the roughly same area. However, in the time of our research DAPL's construction was not approved, and therefore we do not deal with it here.

DOI: 10.1515/eas-2017-0011 C University of SS. Cyril and Methodius in Trnava. All rights reserved. 
they set up a symbolic encampment - "Spiritual Camp" - which became one of the strongest symbols of the protests, and which is situated ${ }^{25}$ approximately ten miles east of official borders of Rosebud Indian Reservation. The Camp was built in the planned route of the Keystone pipeline on tribal lands on a place considered sacred by the Lakota ${ }^{26}$. Men and women who camped there (some come only for several days, some of them stayed for a long period of time with their families being with them or visiting them regularly) were determined to maintain the camp "twenty-four hours a day until either the proposed Keystone XL pipeline permit is denied or the ground gets broken with pipeline construction" (Shield the People 2014).

The Spiritual Camp was built on its place also with the intention to protect one of Lakota sacred places, since it would have been destroyed by the construction of the pipeline. As the photo above illustrates, the occupants sleep in tipis, no matter what is the weather like. Some who stayed in the camp for a long period of time took their pets with them, grew small vegetable gardens next to their tipis, or even sheltered small domestic animals such as chicken. There was also one tent with a gas stove and an electric generator which provides the camp's internet connection - their link with the rest of the world and their main tool of resistance. However, the occupants do not have much comfort in the camp, due to severe weather conditions in the Plains. Despite the hot in summer and frost and wind in winter, the occupation of Spiritual Camp continued all year long until TransCanada announced stopping of the project, and even after that day it is not empty. The Spiritual Camp (or Spirit Camp, as it is called by some) is open for anyone who wants to express his or her sympathies with its idea, which refers directly to the concept of Mitakuye Oyas'i $\eta$ and its application to the issue of the KXL pipeline: If the Lakota allow destroying their land, they will also let their cultural identity be harmed irrecoverably. Shield the People and the Camp's residents do not point out only to the threat of the pollution of drinking water by the possible oil spill from the pipeline, but they protest against the project also for the reason of preserving a spiritual balance within the tribal land. In this context, we can remember, that when Fixico defined the Native concept of "Natural Order of Life" (FIXICO 2009:41-61), he stressed that all Native philosophies operate in a circular mode which opposes the Euro-American linear one. The Lakota protests operate precisely

25 Even though the protests against the pipeline were stopped after the official rejection of the project, the camp still exists on its original place and is occasionally used for inipi ceremonies and gatherings of people.

$26 \quad$ "You'll sleep well here, 'cause there's a good medicine dug in the place." A Lakota resident of the Spiritual Camp. Interview, July 2014.

DOI: 10.1515/eas-2017-0011 C University of SS. Cyril and Methodius in Trnava. All rights reserved. 
according to this logic: apart from environmental impacts of the project, they fear of the breaking the "Circle of Life" through destroying their sacred place and therefore disrupting their children's lives. In other words, history is a part of the present and the future. That is why the Camp carries the name Spiritual and why Lakota protests are culturally bound.

The Spiritual Camp is a place ${ }^{27}$ where people can meet, talk about their common cause the actions against the pipeline - and support each other. One of the purposes of the Camp is also provide the "warriors ${ }^{28}$ " an opportunity to regain strength from prayers, from inipi (sweat lodge) ceremony which takes place almost every day, or just by sharing positive news and thoughts with each other. Many of the visitors donate food, candles, or other equipment needed. People come not only from neighbouring Rosebud and Pine Ridge communities: supporters came from New York or even from Europe ${ }^{29}$. Though the Spiritual Camp is a Lakota project, and is based on Lakota worldview and culture, they made efforts to formulate their protests as fighting for values that the Lakota consider universal since they belong to both Native and non-Native culture Earth and Water is sacred: for the Lakota, and the threat of pollution of water and soil caused by the construction or possible breakdown of the pipeline causes harm not only in material but also spiritual sense, as it was explained above. The Lakota also want the politicians and representatives of TransCanada to understand (and accept) their Native relationship to the environment: one does not own the land he or she lives in; everybody is nothing more than another part of creation in which everything has its place and is connected with all. Shield the People also stresses the importance of children (or the youngest generation) for Lakota people, since they are their future; and parents and grandparents feel the responsibility to fight against the pipeline to protect clean environment for future generations.

The deep spirituality and spiritual fight against the pipeline construction is the primary focus and effort of the people staying in the camp. They say that trough this place, the

27 We have visited the Spiritual Camp repeatedly, in summer 2014 and 2015. The photographs of the Camp were also taken during these visits.

28 The protesters often referred to themselves as „warriors,“ pointing out to the traditional virtues of Lakota men.

29 During our visit in summer 2014 there was a group of four young people from New York who had come across the news about Spiritual Camp accidentally on a social network and they decided to express their sympathies to the Camp's occupants in person. The Spiritual Camp's occupants also remembered a visit from Germany that had arrived to see the camp that same summer. Interviews with the Camp's residents. July, 2014.

DOI: 10.1515/eas-2017-0011 C University of SS. Cyril and Methodius in Trnava. All rights reserved. 
whole tribe stands against the mining company, and the prayers and positive thoughts (spiritual support) send by everyone give the occupants energy to continue their fight.

However, the spiritual unity in protecting water and land does not end at the borders of Rosebud Reservation. As it has been mentioned above, the camp is provided with electricity and internet access, and spreading and sharing the word about the Camp through social networks plays very important role in the protests. Shield the People have their Facebook site and they provide it with news from the camp regularly ${ }^{30}$. The posts are written in a positive and encouraging tone, expressing the hope for a good end of the fight and also stressing the unity of all the camp occupants.

Through their blog and Facebook site, Shield the People can share Native perspective on the fight against the pipeline construction, and also the values they are protecting. The rhetoric and purpose of Shield the People project can be characterized as a peaceful and non-violent protest stressing the necessity of protecting traditional Lakota values, and saving the future of the community. However, these values are presented as universal and going beyond traditional ethnic divisions.

On the other hand, in the Rosebud Sioux Tribe community, we can find different opinions on how the protests should go. When in 2014 the U.S. House of Representatives approved the controversial Keystone pipeline bill, Rosebud Sioux Tribal President Cyril Scott called this an "act of war." As he explained later, by act of war he meant that the Lakota "are going to have to take legal manoeuvres and are going to protect their land and their way of life" (Indian Country Today Media Network 2014).

He expressed the feeling many Lakota people have that the history is repeating itself, and the forced construction of the pipeline near Rosebud would be another case of breaking a treaty made between US federal government and Native Americans:

"When it comes to treaties, they forget about us. ... People forget that we're a sovereign nation. Everybody else ... they're just guests here" (IBANEZ 2014). 
Consequently, many who oppose the KXL pipeline (which is in fact the whole tribe ${ }^{31}$ ), point out primarily to the traditional virtues of a Lakota warrior and their actions and protests are lead in this tradition.

We can say that these two main forms of protest have roots in, and stress the traditional values of the Lakota: respect for the past and the sense of responsibility for the future generations as a part of the circular concept of time, and the Mitakuye Oyas'in concept which stresses people's spiritual connection with the land they live in. Other protests also point out to the heritage of generations of Lakota warriors. However, the fight against Keystone pipeline (or Black Snake as it is sometimes called) gave rise to an alliance, which is more universal, and goes beyond traditional ethnic and cultural distinctions. It is called Cowboy Indian Alliance, and it unites Native Americans and white farmers, ranchers and landowners from South Dakota and Nebraska. However stereotypical its name might sound, the idea to unite people in their fight for land is perceived as a new and very positive change in the society by both sides.

It is true that the alliance stresses the stereotypical imagery from western movies, but it does this on purpose, and there is a tone of irony, and hyperbole in it. These two traditionally alien groups united in a common cause and together they were determined to fight against Federal political decisions that would destroy their homeland where they live, farm, hunt and where their ancestors were buried. We can understand the Cowboy and Indian Alliance as a project in which the Lakota managed to make their concept Mitāikuye Oyas'i i known to farmers in the region and other non-Native people, and in this way their culture and especially their relationship with the environment has become a significant factor in the protests. $^{32}$ Thus their philosophy which has formed their traditions for

31 When we write "the whole tribe" here, we actually mean it. Unlike other issues concerning Lakota cultural identity and cultural revival, which often matter primarily to Lakota ethnic activist, the KXL issue resonates in the whole reservation, and it is familiar both to the Lakota who care of the traditions of their ancestors and to families who have otherwise little interest in Lakota customs or language.

32 The Lakota and their project "Shield the People" is not the only one which links indigenous culture with protests against destruction of environment. Probably the largest and most powerful initiative is the "Idle No More" movement. It was founded by three Native women and one environmental activist. Together the women began to "spread the word" about changes in Canadian and US legislatives which would cause further destruction of environment. They operate primarily through social networks where sharing such news is an effective way of medialisation. At the present time "Idle No More" (INM) describes itself as a platform for all movements, actions and gatherings that fight for the protection of environment. As Jakub Hutera stressed in his work, INM has turned

DOI: 10.1515/eas-2017-0011 C University of SS. Cyril and Methodius in Trnava. All rights reserved. 
hundreds of years has proved to be a concept which can be relevant in and be accepted by the contemporary globalized world and society. That their culturally bound arguments were not ignored by the US society can be also proved by the fact that the news about the Spiritual Camp has got into mainstream media several times. ${ }^{33}$

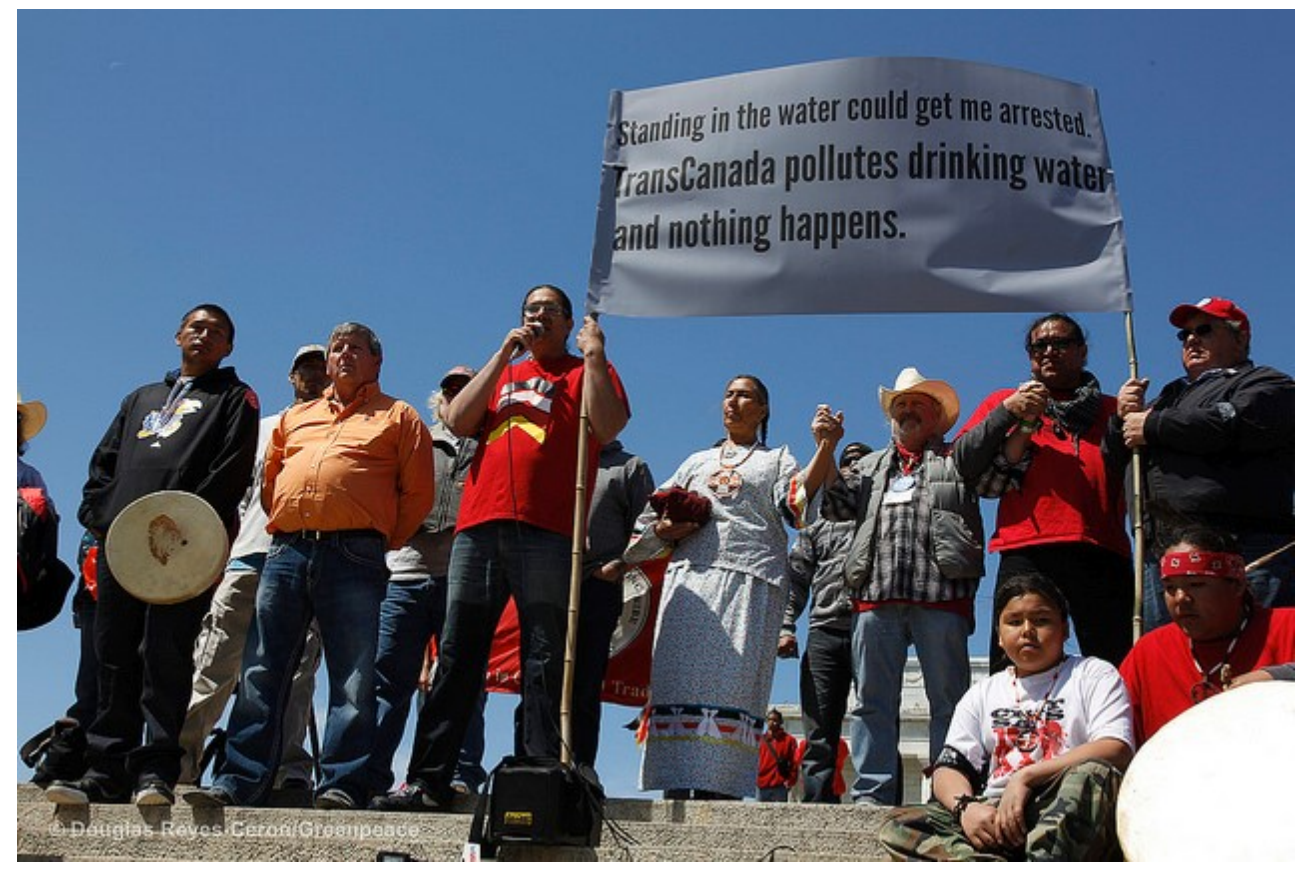

Figure 6: Protest against KXL pipeline. Source: http://rejectandprotect.org.

\section{Those Ways: Religion and Spirituality}

In the passage above, we have dealt with the importance of landscape and environment to the Lakota living in reservations, and about the way it is rooted in their philosophy and metaphysical perception of the world (besides, the name of the Spiritual Camp illustrates it

(Native) culture into a political category (HUTERA, a lecture at Vaclav Havel's Library in Prague, March 2015).

33 For example it appeared in The Ed Show on 31 ${ }^{\text {st }}$ March 2014.

DOI: 10.1515/eas-2017-0011 C University of SS. Cyril and Methodius in Trnava. All rights reserved. 
eloquently). In the following paragraphs, we will deal with the issue of spirituality and what it means for the Lakota in more detail. Though this topic is so wide that it would have needed much more space in order to be researched properly, ${ }^{34}$ we consider necessary to include it here in the passage on Lakota identity and how it can be perceived in a dual mode.

As Bucko writes ${ }^{35}$, religion nowadays is very important for Native peoples and their identity, because it is by many considered the "last thing that the Indian people had left" (BUCKO 2008). He also notes that from Native perspective the term is used interchangeably with "spirituality" and "those ways," and there is often a sense of sentiment expressed with it. At the same time, it is important to realize, that for the Lakota, religion does not represent an isolated category which is separated from their secular lives. On the contrary, it is being lived by the majority of the Lakota every day, though every single individual lives and practices his spirituality in a slightly different form and way, a fortiori, because Lakota religion - similarly to other Native religions - cannot be perceived as something isolated from new influences. Conversely, it is a subject of continuous changes, borrowings and innovations. For all these reasons, it is necessary to perceive spirituality from a perspective which is different from the Western one: "Religion cannot be separated from other cultural institutions such as healing, political structure, hunting, and success in warfare. Religion is interpreted in relation to the other elements of the society" (BUCKO 1998:179).

When we study Lakota religion and its external manifestations on the reservations, there is another important factor which has to be taken into consideration. There are two extreme positions towards spirituality among those who can speak authoritatively about it. On the one hand, religion is perceived as something which is not to be shared with outsiders - as knowledge which is "considered sacred and not shared with outsiders" (PICKERING 2004:21). By many it is perceived as "the last secret and property of the Native community" (BUCKO 1998:173). On the other hand, some religious practices are open to

$34 \quad$ There are many works dealing with the issue of Native spirituality and religion, among which Deloria Jr.'s works are one of the most insightful ones. For more detail see his books God Is Red or For This Land: Writings on Religion in America (DELORIA V.J., Custer Died for Your Sins: An Indian Manifesto, 1969; DELORIA V. J., God Is Red, 2003), DeMallie's The Sixth Grandfather is also a classics (DeMALLIE 1984).

35 Though Bucko often writes about Native American religions in general in his article, he bases many of his observations on his fieldwork in Lakota reservations between years 1988 to 2000 See BUCKO, The Lakota Ritual of the Sweat Lodge: History and Contemporary Practice, 1998.

DOI: 10.1515/eas-2017-0011 C University of SS. Cyril and Methodius in Trnava. All rights reserved. 
free interaction and their sharing with outsiders. Lakota ceremony ${ }^{36}$ of sweat lodge is generally considered a ceremony which is open to anyone ${ }^{37}$ and can be example of an act of sharing of religion.

As it was written, Lakota religion can hardly be perceived as an institutionalized and monolithically unified issue. For this reason, the question of who may speak magisterially about it needs to be considered. Among the Lakota - both with and without university diploma - there have been many initiatives which aim at sharing the knowledge about Lakota religion and spirituality through books. The primary purpose is of course sharing the knowledge, but apart from that Lakota authors often mention the intention to correct some misinterpretations which appeared in previous literature on Lakota spirituality, and whose validity has been strongly questioned ${ }^{38}$. As White Hat Sr. writes, another reason for sharing knowledge which has been considered sacred and secret can be the attempt to overcome fear of traditional beliefs (see the quote from his book in the introduction of the text).

Nowadays, there is a strong role of both traditional Lakota religious practices and Christian church, and they are far from being separated from each other. It has been already mentioned that religion and spirituality is an important part of Lakota identity, and it is common that residents of Lakota reservations incorporate both traditions into their lives. Bucko himself writes about dual participation in the two belief systems, and points out that the Lakota are often "compartmentalizing Native and Christian practices and participating in both at different times and for different purposes." He uses the term "Native Christianity" to describe the process how both traditions form Lakota identity together without devaluation of either of the traditions (BUCKO 2008:186). Example of such duality in religious belief can be illustrated by Lakota general attitude towards two ultimately liminal moments of human existence - birth and death. While the majority of Lakota families prepare the traditional leather turtle to carry the new-born's umbilical cord and a

36 The Sweat lodge ceremony is now practiced among Native Americans accross the whole continent.

37 A resident of the Spiritual Camp. Interview, July 2014.

38 For example, the notorious book Black Elk Speaks by John G. Neihardt was recognized by many as an authentic work on Lakota religion and spirituality. However, as later studies and comparisons have shown, it can hardly be considered as authentic due to Neihardt's edits and omissions. See PICKERING 2004 and NEIHARDT 2008. See also Ullrich's epilogue to the Czech edition of Black Elk Speaks, Mluví Černý Jelen, in which he deals with the issue of religion among the Lakota of Black Elk's time (NEIHARDT 1998:233-310).

DOI: 10.1515/eas-2017-0011 C University of SS. Cyril and Methodius in Trnava. All rights reserved. 
star quilt to ensure the baby's protection and long life, the death of a relative is often reflected through Christian belief in God and resurrection ${ }^{39}$.

\section{Conclusion: Lakota Identity in the Western World}

"The American Indian mind has changed and it has become less traditional. The majority of the Indian population is represented by mixed bloods, and the mixed blood thinks differently from the traditional full blood and he or she thinks more like the linear white man due to attending schools with white teachers" (FIXICO 2009:168).

Fixico's reflection of Native American identity regardless tribal affiliation does not sound very positive and encouraging. Do the Lakota feel similar regret as described by Fixico? Definitely we do not have the authority to answer the question for all Lakota, but let us consider it through issues we have dealt with here. First, several examples from museums run by tribal institutions have shown that the Lakota perceive their cultural heritage, history and present differently from curators of ethnographical museums in the West. Though we can find objects from the period before the Lakota contact with Europeans, the function of such exhibits differ in the two cases. Bucko refers to such objects and elements of culture as "ethnographic present," and notes that it still has some value in study of the Lakota (BUCKO 2008:176-182). Western museums have a long tradition of ethnographers who collected data and material artefacts among "exotic" cultures in what they believed was an uncontaminated state before these cultures would be - in their eyes - lost or radically transformed (BUCKO 2008:179). The trouble is that nowadays Western museums often put too much emphasis as ethnographical present at the expense of current issues among the Lakota (or other Native American culture). However, it this true that ethnographical present is recognized by current Lakota as well. For example, E. C. Deloria has recently written a whole book dealing with the issue ${ }^{40}$. The difference is that ethnographical present is perceived as a part of today's world for the Lakota: great-grandmother's fan used by her grand-daughter at powwows, the spirit of a deceased grandfather still believed to be present in some objects by his family, rituals and ceremonies, or care and love with which children are taught Lakota langue by their family or teachers ${ }^{41}$. In this way, Fixico's view on Native

The wife of the former president of Rosebud Sioux Tribe. Interview, July 2014.

See her book The Dakota Way of Life (DELORIA 2007).

A teacher at Lakota Summer Elementary School. Interview, St. Francis, July 2014.

DOI: 10.1515/eas-2017-0011 C University of SS. Cyril and Methodius in Trnava. All rights reserved. 
culture being circular in contrast with Western emphasis on linearity is relevant. As a consequence, one of the duality the Lakota have to deal with is to live within these two thought systems simultaneously.

\section{Bibliography}

AMES, K. M. (2008): Political and historical ecologies. In T. Biolsi, A Companion to the anthropology of American Indians (pp. 7-23). Malden: Blackwell Publishing.

BERKHOFER, R. F. (1978): The White Man's Indian. New York: Random House.

BUCKO, R. (1998): The Lakota Ritual of the Sweat Lodge: History and Contemporary Practice. Lincoln: University of Nebraska Press.

BUCKO, R. (2008): Religion. In T. Biolsi, A Companion to the Anthropology of American Indians (pp. 171-195). Malden: Blackwell Publishing.

CASH, J. H. (1995): To Be an Indian. St. Paul: Minnesota Historica Press.

DE SAUSSURE, F. (1915): Course in General Linguistics. Chicago: Open Court.

DELORIA, E. C. (2007): The Dakota way of Life. Rapid City: Mariah's Press.

DELORIA, V. J. (1969): Custer Died for Your Sins: An Indian Manifesto. New York: MacMillan.

DELORIA, V. J. (2003): God is Red. Golden: Fulcrum Publishing.

DeMALLIE, R. J. (1984): The Sixth Grandfather. Black Elk's teachings given to John G. Neihardt. Lincoln: University of Nebraska Press.

IBANEZ, C. (2014, March 13): Lakota vow: 'dead or in prison before we allow the KXL pipeline'. Retrieved from Waging nonviolence: www.wagingnonviolence.org.

Indian Country Today Media Network. (2014, November 17): Rosebud Sioux Tribe Calls House Keystone XL Passage an 'Act of War,' Vows Legal Action. Retrieved from Indian Country Today Media Network: www.indiancountrytodaymedianetwork.net.

LABOTT, E. (2015, November 6): CNN news. Retrieved from Obama rejects Keystone Pipeline: www.cnn.com.

LINCOLN, K., - SLAGE, A. L. (1997): The Good Red Road. Lincoln: University of Nebraska Press. 
McNICKLE, D. (1993): Native American Tribalism: Indian Survivals and Renewals. Oxford: Oxford University Press.

MSNBC (2014, March 31): The Ed Show. Retrieved from MSNBC: www.msnbc.com. NAPESNI, O. (2003): Salt Camp, HerStory: Lakota Living Treasure. Victoria: Trafford Publishing.

National Museum of the American Indian. (1994): All Roads Are Good: Native Voices on Life and Culture. Washington: Smithsonian Institution Press.

NEIHARDT, J. G. (1998): Mluví Černý jelen. Praha: Hynek.

NEIHARDT, J. G. (2008): Black Elk Speaks. Albany: State University of New York Press.

PICKERING, K. (2004, March): Decolonizing Time Regimes: Lakota Conception of Work, Economy and Society. American Anthropologist, 106(1), pp. 85-97.

Shield the People. (2014, March): Retrieved from Shield the People: www.shieldthepeople.org.

SMITH, L. T. (1999): Decolonizing Methodologies. London: Zed Books Ltd.

VALANDRA, E. C. (2006): Not without Our Consent. Champaign: University of Illinois Press.

WHITE HAT, A. (2012): Life's Journey - Zuya. Salt Lake City: University of Utah Press. 